\title{
The Role of Students' Motivation in the Relationship between Perceived Learning Environment and Achievement in Science: A Mediation Analysis
}

\author{
Aslihan Hafizoglu', Sundus Yerdelen ${ }^{2 *}$ \\ ${ }^{1}$ Turkish Ministry of National Education, Science Teacher, Alicoren Middle School, Bolu, Turkey, ${ }^{2}$ Department of Mathematics and Science Education, \\ Kafkas University, Faculty of Education, Kars, Turkey
}

*Corresponding Author: suyerdelen@gmail.com

\section{ABSTRACT}

The purpose of this study was to investigate the mediating role of $7^{\text {th }}$ grade students' motivation toward learning science in the relationship between their science learning environment perceptions and science achievement. The correlational research design was utilized in this study and data were collected from $9227^{\text {th }}$ grade students using self-report questionnaires and a multiple-choice science achievement test. While motivation to learn science was regarded as self-efficacy, task value, intrinsic goal orientation, and extrinsic goal orientation, students' perceptions of the learning environment in science class were assessed by considering the components of constructivist learning environment such as teacher support, involvement, investigation, and equity. The results are discussed in relation to the features of classroom learning environment related to students' performance in science class. According to the results obtained from latent variables path analyses, it seems important that classroom learning environments which were arranged by means of the perspective of the constructivist learning environment increase students' science achievement directly and indirectly by increasing their motivation toward science.

KEY WORDS: achievement; learning environment; motivation; self-efficacy; science education

\section{INTRODUCTION}

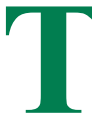
he classroom learning environment has been a research area for educational researchers for whom students' classroom environment has been considered as a key place for determining students' learning (Fraser, 1994, 1998). According to Wilson (1996), the classroom learning environment can be defined as a place where students and teachers communicate with each other, and many kinds of materials and knowledge are used for learning activities. Fisher et al. (1995) pointed out that a positive classroom learning environment was a vital factor in students' academic performance and attitudes. Similarly, in several studies, students' classroom learning environment perceptions were found to be one of the significant predictors for students' academic achievement (e.g., Arisoy, 2007; Baek \& Choi, 2002; Dorman, 2001; Margianti et al., 2002; Pamuk et al., 2017).

Based on social cognitive theory, Bandura (1986) stated that learning refers to a multifaceted system that depends on the learner's characteristics, behaviors, social environment, and reciprocal interaction of these variables. Therefore, it is vital to examine the psychosocial features of the learning environment and their relation to motivation toward learning and achievement. Findings of various studies have provided empirical evidence that students' learning environment perceptions are related to various cognitive and affective learning outcomes (Fraser, 1998) such as students' achievements, motivation, metacognition, self-regulation, and achievement goal orientation (Ames, 1992; Chionh \& Fraser, 2009; Lau \& Lee, 2008). For instance, when students perceive their classroom to be high in cooperation they progress academically, and their affective outcomes (e.g., selfesteem and supportive relationships) toward school become positive (Johnson et al., 1983). Partin and Haney (2012) found that students who perceive their classroom learning environment as positive, state a higher level of self-efficacy beliefs, and as such, their course performance improves. Moreover, Peters (2013) found that self-efficacy mediated the relationship between perceived learning environment and math achievement of college students. Sungur and Gungoren (2009) also revealed that in the domain of science, students' self-efficacy beliefs, mastery and performance goals had a mediating role in the correlation between learning environment perceptions and achievement scores of students. There are studies in the science education field, which generally have shown the significant association between classroom environment, achievement, and students' motivation (Aldridge \& Fraser, 2000; den Brok et al., 2004; Telli et al., 2006; Wahyudi \& Treagust, 2004; Yerdelen, 2013).

\section{Students' Motivation to Learn Science}

Student motivation can be defined as exciting the students' mind to grasp instruction (Crump, 1995). Viau (2015) also 
proposed that motivation results from students' perceptions about themselves and their environment, focusing students to do and finish educational activities. Furthermore, many studies implied that motivation is the most important factor influencing students' academic achievement (Pintrich \& Schunk, 2002) and constructing students' learning (Brophy, 1998; Lee and Brophy, 1996). Consequently, researchers have reported that students who lacked academic success also had low motivation toward related lessons (Andrew and Vialle, 1998; Schunk, 1991; Singh et al., 2002). In addition, Barlia (1999) revealed that students should be motivated towards science lessons so as to progress their science learning. In the same manner, Brossard et al. (2005) claimed that within the affective outcomes, motivation has taken a crucial role in achieving meaningful science learning in the classes.

Several studies have illustrated that there was an association between classroom learning environment and students' motivational factors such as self-efficacy belief, mastery, and performance goal orientations (Ames, 1992; Brophy, 2004; Fraser, 1998; Greene et al., 2004). In the present study, as motivation includes various aspects, we considered academic self-efficacy, achievement goal orientation, and task value as motivational variables since they are both the most frequently studied indicators of motivation and found to be correlated with science achievement and the learning environment.

\section{Self-efficacy}

Bandura (1981) claimed that self-efficacy refers to students' self-perception related to their ability to succeed in learning tasks. Bandura (1981) also suggested that when students have high levels of self-efficacy beliefs, they have the potential to succeed in learning assignments, whether these assignments are difficult or not. Some theorists of educational psychology (e.g., Bandura, 1997; Pajares, 1996; Pintrich \& Schunk, 2002) have argued that students having low self-efficacy beliefs keep away from participating in a task, and they are expected to stop trying when faced with difficulties, even if they are capable of achieving the assignments. Linnenbrink and Pintrich (2003) also highlighted that self-efficacy is a predominant motivational variable that encourages students' learning, attitudinal, and cognitive engagements. Likewise, Singh et al. (2006) reported that a student's science self-efficacy has a direct correlation with the student's task orientation and science grade. Similarly, Britner and Pajares (2006) emphasized that students' science grades were predicted by their self-efficacy beliefs.

\section{Achievement Goal Orientation}

Based on achievement goal theory, students' learning goals direct and activate their attitudes in achievement circumstances (Ames, 1992; Pintrich, 2000). Two major goal orientations: Mastery and performance goal orientations are the most commonly used by motivation researchers (Pintrich, 2003). Pintrich and Schunk (2002) explained that mastery goals are concerned with maintaining to learn and progress on a task, to improve new abilities, and to obtain new perceptions about doing the task. In addition, with a mastery goal, students are oriented toward learning by satisfying their innate needs and curiosity (Hidi \& Renninger, 2006). When students adopt mastery goals, they tend to do challenging works and take risks (Ames \& Archer, 1988). At the same time, mastery goals substantially raise the amount of time children to spend when doing tasks (Butler, 1987) and students' determination when encountering difficulties (Elliot \& Dweck, 1988). On the other hand, according to Pintrich and Schunk (2002), performance goals are associated with adopting to illustrate one's competence to others, to get awards from teachers, and friends, and to perform better than others in the class when working learning tasks. Furthermore, it is crucial for performance-oriented students to obtain high scores in exams and to be the best in class while performing tasks (Pintrich, 1999). In light of the findings of the study conducted by Barron and Harackiewicz (2001), it can be implied that there is a positive relationship between students' performance goals and their academic achievements (final grades). Although mastery and performance goals emphasize different achievement orientations, students may develop both of them toward a specific learning subject (Dowson \& McInerney, 2003). Therefore, in the present study, we identified mastery and performance goal orientations as the indicators of motivation toward science learning. Although, in their $2 \times 2$ achievement goal approach, Elliot (1999) distinguished these goals into avoidance and approach, in the scope of this study we avoided including avoidance aspects as sometimes they may be negatively related to students' performance (e.g., Bargezar, 2012; Elliot \& McGregor, 2001; Tas, 2008; Wolters, 2004; Yerdelen, 2013) and motivational variables (Elliot \& Church, 1997; Liem et al., 2008; Pajares et al., 2000). To illustrate, Yerdelen (2013) found out a positive association between students' mastery approach goals and achievement scores in science; however, performance avoidance goals of the students were negatively correlated with performance-avoidance goals.

\section{Task Value}

In addition to achievement goals and self-efficacy beliefs, task value is considered as a substantial factor in students' academic motivation (Brophy, 1998; Pintrich \& Schunk, 2002). Task value can also be explained as students' own concern toward attaining a goal and their perceptions regarding the importance of the learning tasks (Eccles, 1983). Students' task value beliefs are related to the intrinsic excitement obtained through achieving the task process (Eccless, 1983). When students develop task value they are prone to study efficiently, set new learning goals and struggle to overcome difficulties (Wigfield, 1994). In several studies, students' task value beliefs have been found to be significantly and positively correlated with their academic achievements (Bong, 2001; Lavasani et al., 2010; Pintrich \& Schunk, 2002; Yumusak et al., 2007).

\section{Current Study}

As stated, students' classroom learning environment and their motivation have a crucial role on their academic achievements. Even though the classroom learning environment has been a frequently studied research area among educational researchers, 
the mediating role of students' motivation toward learning on the relationship between students' learning environment perceptions and achievement has been rarely empirically examined (e.g. Ahmed et al., 2010; Patrick et al., 2007). There are studies emphasizing the fact that learning environments influence students' motivation; and their motivation, in turn, affects students' learning (Eccles, 2007; Wentzel, 1998). Therefore, the aim of this study was to test the mediating role of motivation between students' science achievement and constructivist learning environment perceptions as shown in the hypothesized model in Figure 1.

In addition, the present study was concerned with the field of science education due to the fact that the results of some international assessment studies (e.g., Trends in International Mathematics and Science Study conducted in 1999 and 2007, and Programme for International Student Assessment conducted in 2006 and 2009) revealed that when compared with other countries' students' science scores, Turkish students' science mean scores were considerably lower (Ministry of National Education of Turkey [MoNE], 2005, 2010a, 2010b, 2011). Therefore, it seems essential to analyze the variables related to Turkish students' academic achievement in a science lesson. In the domain of science, it has been observed that students' motivational variables were strongly associated with classroom learning environments (e.g., Britner and Pajares, 2006; Dorman, 2001; Dorman et al., 2006). However, the mediating role of the motivational variables between the science learning environment and science achievement has been often overlooked with the except of a few studies in the field of science education (e.g., Sungur \& Gungoren, 2009; Pamuk et al., 2017; Yerdelen, 2013). Thus, this study is expected to contribute to this gap in literature. Therefore, the main research question guiding this study is:

How do $7^{\text {th }}$ grade students' motivation towards learning science mediate the relationship between their perceptions of science learning environment and their science achievements?

\section{MATERIALS AND METHODS}

Survey method was used in this study and data were collected in the spring semester of 2016-2017 academic

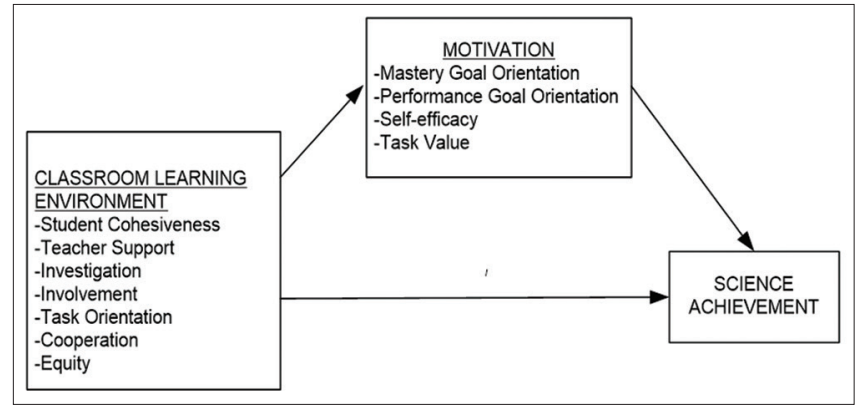

Figure 1: Hypothesized model about the mediator role of motivation in the relationship between the perceived learning environment and science achievement year using self-report questionnaires and a multiple-choice achievement test.

\section{Sample}

Only middle schools located at the city center of the Kars Province of Turkey were included in the study. Thirteen of the 16 schools were willing to participate. Therefore, data were collected from all of the $7^{\text {th }}$-grade students $(n=922)$ from eleven public and two private schools. Therefore, $9227^{\text {th }}$ grade middle school students participated in this study. Of these students, 450 (48.8\%) were girls, 462 (50.1\%) were boys, and $10(1.2 \%)$ did not indicate their gender. The mean age of the students was $13(\mathrm{SD}=0.87)$ and students' average science grade of the previous semester was 78.42 out of 100 $(\mathrm{SD}=16.37)$.

\section{Instruments}

What Is happening in this classroom? Questionnaire (WIHIC): To measure the students' learning environment perceptions in science class, the WIHIC questionnaire was utilized. The original form of the instrument was developed by Fraser et al. (1996), and revised by Aldridge and Fraser (2000). Its current version consists of seven subscales and 56 items. The subscales of the WIHIC are composed of student cohesiveness (e.g., "I work well with other class members"), teacher support (e.g., "The teacher's questions help me to understand"), involvement (e.g., "I discuss ideas in class"), investigation (e.g., "I find out answers to questions by doing investigations"), task orientation (e.g., "I know the goals for this class"), cooperation (e.g., "I cooperate with other students when doing assignment work"), and equity (e.g., "I am treated the same as other students in this class"). Each subscale includes eight items and the response scale is based on a 5-point Likert scale ranging from Almost Never (1) to Almost Always (5). This instrument was translated and adapted into Turkish by Telli et al. (2006), Cronbach's alpha coefficients of the subscales ranged from 0.75 to 0.88 . The present study's reliability coefficients ranged between 0.86 and 0.87 .

Motivated strategies for learning questionnaire (MSLQ): Students' motivation toward science learning was measured by the four subscales of Motivated Strategies for Learning (MSLQ) questionnaire (Pintrich and De Groot, 1990). First, students' mastery and performance goal orientations were measured using intrinsic goal orientation (four items, e.g., "In the science class, I prefer course material that challenges me so I can learn new things."), and extrinsic goal orientation (four items, e.g., "If I can, I want to get better grades in this science class than most of the other students.") subscales, respectively. In addition, task value (six items, e.g., "I think I will be able to use what I learn in this science course in other courses."), and self-efficacy for learning and performance (eight items, e.g., "Considering the difficulty of this course, the teacher, and my skills, I think I will do well in this science class.") subscales of the instrument were used to evaluate students' task value and self-efficacy levels. The response scale of the instrument is based on a 7-point Likert scale ranging from 1 (Not all true 
of me) to 7 (Very true of me). The MSLQ was adapted into Turkish by Sungur (2004) and Cronbach's alpha coefficients of these subscales were found to range between 0.54 and 0.89 . The internal consistency coefficients (Cronbach's alpha) of the subscales obtained from this study ranged from 0.80 to 0.83 .

Science achievement test (SAT): With the purpose of measuring students' science achievements, a 16-item SAT was developed by the researchers. The total class hours per unit and number of instructional objectives in $7^{\text {th }}$-grade science curriculum were taken into account when it was developed. For validity and reliability of the test, the items were selected among science test implemented in national exams by MoNE. The SAT includes $7^{\text {th }}$-grade units from the fall semester. To validate the test, a pilot study was conducted. After the pilot study, the total number of items in the SAT decreased from 25 to 16 . The reliability coefficient obtained from the main study using Kuder Richardson 20 formula was 0.79 . The discrimination indices of the SAT were between 0.41 and 0.77 while item difficulty levels ranged from 0.33 to 0.75 .

\section{RESULTS}

\section{Descriptive Statistics}

The means and standard deviations for each scale were computed using SPSS 20.0 program. As shown in Table 1, the mean scores for students' science learning environment variables were all above the midpoint of the 5-point Likert scale. The mean scores ranged from 3.48 (investigation) to 4.15 (task orientation). This meant that, on average, students had mid to high levels of each variable. Likewise, mean scores for mastery goal orientation, performance goal orientation, task value, and self-efficacy were found to be above the midpoint of the 7-point Likert scale which indicated that students had a tendency to have mid to high levels of motivation toward science learning. In addition, students' science achievement mean score was computed as 9.46 out of $16(\mathrm{SD}=3.72)$.

\begin{tabular}{|c|c|c|c|c|c|}
\hline Variables & $\begin{array}{l}\text { Number } \\
\text { of items }\end{array}$ & M & SD & Scale & Reliability \\
\hline \multicolumn{6}{|l|}{ Learning environment } \\
\hline Student cohesiveness & 8 & 3.74 & 0.72 & $1-5$ & $0.87^{\mathrm{a}}$ \\
\hline Teacher support & 8 & 3.50 & 0.92 & $1-5$ & $0.87^{\mathrm{a}}$ \\
\hline Involvement & 8 & 3.64 & 0.82 & $1-5$ & $0.86^{\mathrm{a}}$ \\
\hline Investigation & 8 & 3.48 & 0.91 & $1-5$ & $0.87^{\mathrm{a}}$ \\
\hline Task orientation & 8 & 4.15 & 0.69 & $1-5$ & $0.87^{\mathrm{a}}$ \\
\hline Cooperation & 8 & 3.54 & 0.88 & $1-5$ & $0.87^{\mathrm{a}}$ \\
\hline Equity & 8 & 3.86 & 0.87 & $1-5$ & $0.86^{\mathrm{a}}$ \\
\hline \multicolumn{6}{|l|}{ Motivational beliefs } \\
\hline Mastery goals & 4 & 5.54 & 1.41 & $1-7$ & $0.83^{\mathrm{a}}$ \\
\hline Performance goals & 4 & 5.70 & 1.32 & $1-7$ & $0.83^{\mathrm{a}}$ \\
\hline Task value & 6 & 5.67 & 1.26 & $1-7$ & $0.80^{\mathrm{a}}$ \\
\hline Self-efficacy & 8 & 5.56 & 1.26 & $1-7$ & $0.80^{\mathrm{a}}$ \\
\hline Science achievement & 16 & 9.46 & 3.72 & $0-16$ & $0.79^{\mathrm{b}}$ \\
\hline
\end{tabular}

\section{Inferential Statistics}

In this step, the previously hypothesized model (Figure 1) was tested using latent variables path analysis using LISREL 8.8 (Jöreskog \& Sörbom, 2007) program. The latent variable, which was named as motivation, was composed of four observed variables including mastery goal orientation, performance goal orientation, task value, and self-efficacy. Moreover, the learning environment variable which indicated students' perception of their science learning environment was formed as a latent variable that consisted of teacher support, student cohesiveness, investigation, task orientation, involvement, cooperation, and equity variables. The achievement variable was also identified as a latent variable, which has only one observed variable computed using achievement test scores. The error term of the science achievement variable was fixed to zero since it represents the whole variance of the science achievement latent variable.

Next, to test the mediating role of the motivation variable between the learning environment perceptions and science achievement, Sobel test (Sobel, 1982) was conducted for these three latent variables using the regression coefficients of the tested models, and standard error values. In all these procedures, the following models were tested respectively based on the mediating variable approach of Baron and Kenny (1986).

Model 1: As seen in Figure 2, first, the predictor variable (learning environment) should significantly predict the criterion variable (science achievement) (Baron \& Kenny, 1986). This test was performed to establish that a relationship existed between the predictor and the criterion variable to ensure that this relationship could be mediated by another variable. The regression coefficient for path $\mathrm{c}$ was obtained through this test. Regression coefficients and standard errors obtained from this study are given in Figure 3. In addition, model fit indices are presented in Table 2 . The results

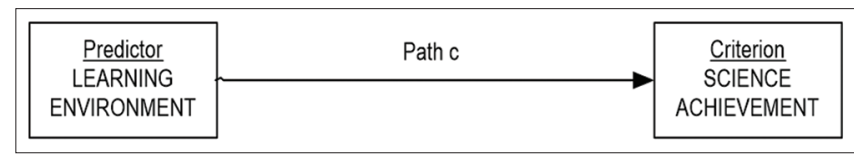

Figure 2: Proposed path c model (model 1)

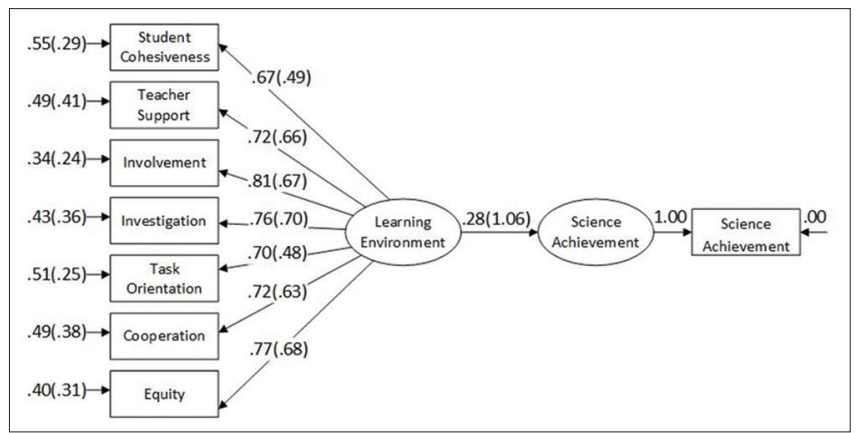

Figure 3: Path c model (model 1) with standardized coefficients. Values in the parenthesis show unstandardized regression coefficients and all arrows have significant coefficients $(\rho<0.05)$ 
presented a good model fit to the data, and students' learning environment perceptions significantly and positively predicted their achievement scores, $\beta_{\text {(path c) })} 0.28, \mathrm{t}=8.37, \rho<0.05$. Learning environment perception accounts for $8 \%$ of the variance in science achievement $\left(\mathrm{R}^{2}=0.08\right)$.

Model 2: In this step, as seen in Figure 4, the predictor variable (learning environment) should predict the mediator variable (motivation) significantly (Baron \& Kenny, 1986). In this model, the mediator variable acts as the criterion variable. At the end of this test, the regression coefficient for path was gained. The diagram of the path model formed in the current study is given in Figure 5, and the results are presented in Table 2. The results showed good model fit to the data set and learning environment significantly and positively predicted science motivation, $\beta_{\text {(path a) }}=0.65, \mathrm{t}=17.23, \rho<0.05$. Learning environment perception accounted for $42 \%$ of the variance in motivation scores $\left(\mathrm{R}^{2}=0.42\right)$.

Model 3: Finally, the effect of the mediating variable (motivation) on the criterion variable (science achievement) was tested, as shown in the model in Figure 6. Path b regression coefficient should be statistically significant in this model (Baron \& Kenny, 1986). Furthermore, in this model, if the mediating variable fully mediates the relationship between the predictor variable and the criterion variable (that is; the effect of the mediating variable is controlled), the regression coefficient of path $\mathrm{c}^{l}$ should be 0 . However, if the motivation variable has partial mediation effect, the regression coefficient of path $\mathrm{c}^{l}$ should be considerably lower than the regression coefficient of path c. In this step, the results of path analysis including the mediating variable, predictor variable, and criterion variable are presented in Table 2. According to these results, model 3 also showed good model fit to the data set.

In this final step, Figure 7 illustrates the regression coefficients between observed and latent variables in the main model tested by latent variables path analysis. Based on the results, students' motivation toward learning science positively and significantly

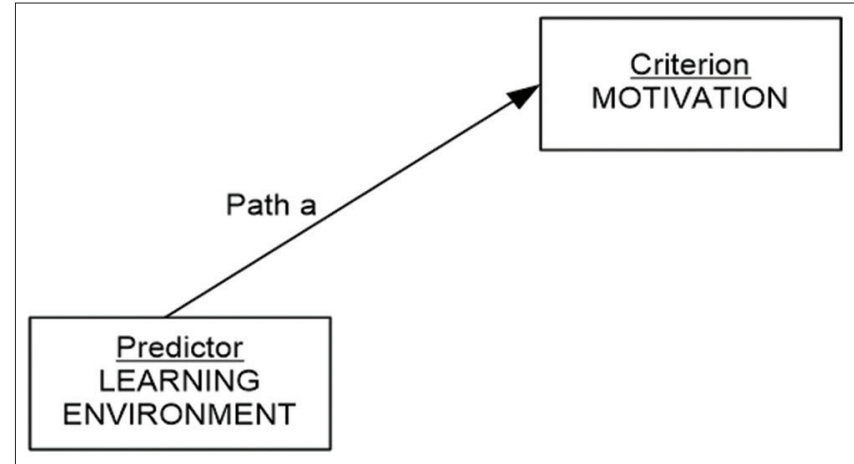

Figure 4: Proposed path a model (model 2)

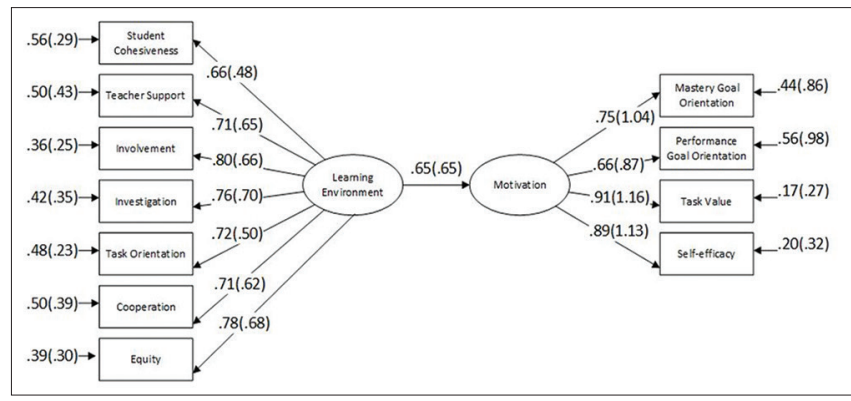

Figure 5: Path a model (model 2) with standardized coefficients. Values in the parenthesis show unstandardized regression coefficients and all arrows have significant coefficients $(\rho<0.05)$

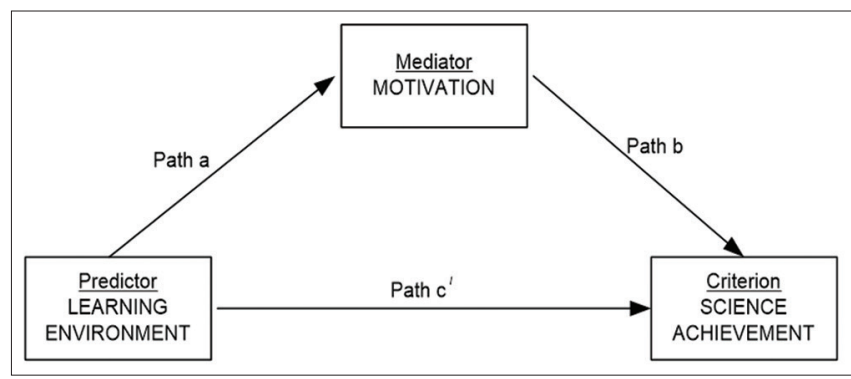

Figure 6: Proposed mediator variable model (model 3)

Table 2: Results of path analyses tested for mediator effect of motivation between science achievement and learning environment perceptions

\begin{tabular}{|c|c|c|c|c|c|c|}
\hline \multicolumn{2}{|l|}{ Steps in mediation analysis } & B & $\boldsymbol{\beta}$ & se & $t$ & Model fit indices \\
\hline Model 1 (Path c) & & & & & & \\
\hline Learning environment $(\mathrm{P})$ & Science achievement (C) & 1.06 & 0.28 & 0.13 & $8.37 *$ & $\begin{array}{c}\text { Chi-square }=158.29, \mathrm{df}=20, \mathrm{SRMR}=0.037 ; \\
\text { RMSEA }=0.087, \mathrm{CFI}=0.98 ; \mathrm{IFI}=0.98 ; \mathrm{NNFI}=0.97, \\
\text { GFI }=0.96\end{array}$ \\
\hline
\end{tabular}

Model 2 (Path a)

Learning environment $(\mathrm{P}) \rightarrow$ Motivation $(\mathrm{C})$

$\begin{array}{llll}0.65 & 0.65 & 0.04 & 17.23 *\end{array}$

Chi-square $=342.14, \mathrm{df}=43, \mathrm{SRMR}=0.057$; RMSEA $=0.087, \mathrm{CFI}=0.98 ; \mathrm{IFI}=0.98 ; \mathrm{NNFI}=0.97$, $\mathrm{GFI}=0.94$

Model 3 (Path b and Path $\mathrm{c}^{1}$ )

$\begin{array}{lllllll}\text { Motivation }(\mathrm{M}) & \rightarrow & \text { Science achievement }(\mathrm{C}) & 0.40 & 0.11 & 0.17 & 2.29 *\end{array}$

Learning environment $(\mathrm{P}) \quad \rightarrow \quad$ Science achievement $(\mathrm{C}) \quad \begin{array}{lllll}0.81 & 0.22 & 0.17 & 4.66^{*}\end{array}$

Chi-square $=386.85, \mathrm{df}=50, \mathrm{SRMR}=0.055$; RMSEA $=0.084$, CFI $=0.97 ;$ IFI $=0.97 \mathrm{NNFI}=0.97$, GFI $=0.93$

${ }^{*} \rho<0.05,(\mathrm{P})$ : Predictor, (M): Mediator, (C): Criterion 


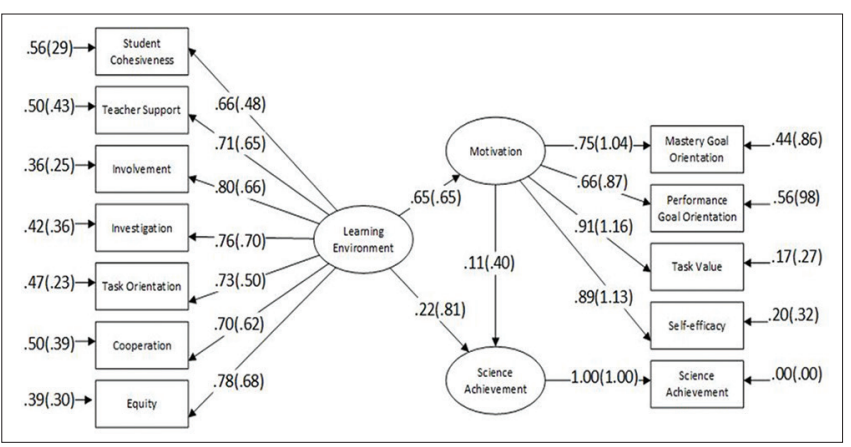

Figure 7: Mediator variable model (model 3) showing standardized coefficients. Values in the parenthesis show unstandardized regression coefficients, and all arrows have significant coefficients $(\rho<0.05)$

predicted their science achievements, $\beta$ (path $b$ ) $=0.11$, $\mathrm{t}=2.29, \rho<0.05$. In addition, science learning environment was found to be a positive and significant predictor of science achievement, $\beta$ (path $\left.\mathrm{c}^{1}\right)=0.22, \mathrm{t}=4.66, \rho<0.05$. Learning environment perception and motivation variables accounted for $8.6 \%$ of the total variance in science achievement $\left(\mathrm{R}^{2}=0.09\right)$. Thus, the higher students' perceptions about science learning environments, the higher their motivation is, and consequently, their science achievement increases.

Finally, the mediating role of the motivation variable between learning environment and science achievement was tested using Sobel test. Sobel test equivalence computes a standard error and $\mathrm{z}$ value with the formula presented below (MacKinnon et al., 1995):

$$
\begin{gathered}
\text { Sobel se }=\sqrt{[b \times s \mathrm{e}(\mathrm{a})]^{2}+[a \times s e(\mathrm{~b})]^{2}} \\
Z=\text { Indirect effect / sobel se }=a \times b / \sqrt{\left[\begin{array}{l}
{[b \times s \mathrm{e}(\mathrm{a})]^{2}} \\
+[a \times s e(\mathrm{~b})]^{2}
\end{array}\right.}
\end{gathered}
$$

Moreover, the effect of the predictor variable on the criterion variable is calculated by $\mathrm{B}=\mathrm{B}_{\mathrm{a}} \times \mathrm{B}_{\mathrm{b}}$ formula, and the standardized indirect effect is computed by the formula of $\beta=\beta_{\mathrm{a}} \times \beta_{\mathrm{b}}$. The effect of the predictor variable on the criterion variable because of motivation is calculated by $\left(\mathrm{B}_{\mathrm{c}}-\mathrm{B}_{\mathrm{c}}{ }^{l}\right) / \mathrm{B}_{\mathrm{c}}$ formula. Based on the calculations using these formulas, students' learning environment perceptions predicted their science motivation; their motivation also positively and significantly predicted their science achievements (indirect effect: $\mathrm{B}=0.65 \times 0.40=0.26$; standardized indirect effect: $\left.\beta=0.65 \times 0.11=0.07 ; z_{\text {sobel }}=2.33 ; \rho=0.020\right)$. Hence, 1 standard deviation (1 score) increase in students' learning environment perceptions is related to 0.65 standard deviations ( 0.65 scores $)$ increase in their motivation and 0.11 standard deviation $(0.40$ scores) of this increase is transferred to students' science achievement. Therefore, since learning environment perception had both a direct effect $(\mathrm{B}=0.81)$ and an indirect effect $(B=0.26)$ on science achievement, the total effect was found to be $\mathrm{B}_{\text {total }}=(0.81+0.26=0.107)$. Moreover, the proportion of the effect of learning environment on science achievement because of motivation's mediating effect was found to be
$\mathrm{B}=(1.06-0.81) / 1.06=0.24$. Therefore, $24 \%$ of the effect on students' science learning environment perceptions on science achievement is due to motivation.

\section{DISCUSSION AND CONCLUSIONS}

The results of the study showed that students who perceive their learning environment positively also have a generally high level of science motivation. The findings are in line with previous research reporting significant relationships between students' motivational variables (e.g., goal orientation of mastery and performance approach, self-efficacy beliefs, and task value) and psychosocial aspects of classroom learning environment (Ames, 1992; Ames \& Archer, 1988; Patrick et al., 2007; Wentzel, 1998; Wentzel \& Battle, 2001). Furthermore, less supportive classroom environments related to teacher caring and student-student interaction in academic work have been linked to decreases in motivation, and academic achievement (Barber \& Olsen, 1997; Ryan \& Patrick, 2001). Similarly, it was emphasized that students may have many more opportunities to increase their motivational beliefs when they are supported by their teachers in their classroom learning environments (Brophy, 2004; Fraser, 1998; Hardre et al., 2008; Urdan \& Schoenfelder, 2006). Likewise, Fosnot (1996) proposed that thanks to constructivist learning environments, students can be motivated intrinsically and have higher self-efficacy. Therefore, the students identify themselves as more competent in the cognitive field. However, there are also some studies stating negative or no association between students' motivational variables and some constructs of classroom learning environment such as student cohesiveness, cooperation, and teacher support (e.g. Dorman, 2001; Dorman et al., 2003).

Based on the present study, both science motivation and science achievements were significantly predicted by students' science learning environments. If students have constructivist learning environments that encourage them to make more investigations, cooperations, and involvements during the learning process, their science motivation becomes higher. Student-student and student-teacher interactions also significantly influence students' motivation toward science learning. Therefore, when students make good friendships with other students, help each other, and their teacher behaves equally toward all students, takes care of them, students are more easily motivated toward science learning. For that reason, it can be inferred that to increase students' science motivation; science learning environments should be created based on a constructivist approach. This finding is supportive of the results obtained in previous research studies (e.g., Baek \& Choi, 2002; Dorman, 2001; Synder, 2005; Rakıc1, 2004; Yerdelen, 2013). Synder (2005) also stated that students' science learning environment perceptions account for $10 \%$ variance in their science achievements. However, den Brok et al. (2010) found no significant association between students' classroom learning environment perception and their biology scores. On the contrary, in the present study, classroom 
environment perceptions predicted a significant amount of the variance in student motivation (42\%), which is much higher than the predicted variance in science achievement by classroom learning environment perceptions (8\%). Thus, it can be stated that a constructivist learning environment has a more influential role in students' motivation toward learning science than science achievement. However, it should be noted that the achievement test used in this study is based only on a multiple-choice test which may not be sufficient to examine students' science achievement. Although these types of multiple-choice achievement tests have been frequently used in national exams in Turkey, they might be weak to assess the science learning outcomes in constructivist learning environments. Here, we suggest using performance evaluation tools to obtain more valid results for educational researchers who have an interest in this research area.

The current study also showed that students' motivation toward learning science significantly predicted their science achievements. This finding means that students having high/ low success in science lessons also have high/low motivation toward science learning. Moreover, the result is supported by much research (Britner \& Pajares, 2006; Pintrich \& De Groot, 1990; Y1ldırım, 2012; Wolters, 2004). To illustrate, it was emphasized that there was a positive correlation between students' science achievements and goal orientations, selfefficacy, and task value beliefs (Britner, 2008; Britner \& Pajares, 2006; Gungoren, 2009; Schunk, 1989; Tas, 2008). Kremer and Walberg (1981) stated that there was a positive correlation between students' motivational beliefs and learning science. Oliver and Simpson (1988) also found that students' motivation toward learning science affects their academic achievement. Moreover, self-efficacy is positively correlated with academic achievement and students with higher levels of self-efficacy have a tendency to make much more effort in learning and show determination when experiencing difficulties (Bandura, 1993). Furthermore, mastery and performanceapproach goals have a fostering effect on achievement and task persistence (Elliot et al., 1999; Williams \& Gill, 1995).

Finally, the main purpose of this study was to investigate the mediating role of motivation; our findings supported our hypothetical model, as shown in Figure 1. Although a large number of studies demonstrated the effect of classroom learning environment on students' academic achievement (Fraser and Walberg 2005; Fraser \& Kahle 2007; Lüdtke et al., 2009; Wentzel and Battle, 2001), few studies examined how learning environments interact with motivational beliefs in predicting students' academic achievements. The results obtained from latent variable path analysis indicated that students' science motivation had a partial mediation effect on science learning environment perceptions. This implies that students' science learning environment perceptions had both direct and indirect effects (because of students' science motivation) on students' science achievements. Therefore, it can be inferred that constructivist learning environment features have a stronger direct effect on students' motivation toward learning science than on science achievement. When considering the constructivist learning environments which provide opportunities for students to construct their knowledge, get support from the teacher and classmates, make investigations about course topics, join class discussions and share their ideas with others, developing high motivation is not surprising and high motivation is generally associated with high achievement (Ahmed et al., 2010; Partin \& Haney, 2012; Patrick et al., 2007; Sungur \& Gungoren, 2009; Talton $\&$ Simpson, 1987). These findings are promising since students mostly have low levels of motivation toward learning science (Galton, 2009; Koballa \& Glynn, 2007; Osborne et al., 2003) and find science subject difficult to understand (Cassels and Johnstone, 1983; Gardner, 1975). As a result, this study gives important insights into the features of effective learning environments, which have a highly positive influence on students' motivation toward learning science.

\section{IMPLICATIONS AND RECOMMENDATIONS}

This study is likely to supply some implications for teachers and teacher educators in science education. The findings showed that improving students' perceptions of science learning environments may enhance students' motivation, and thereby science achievement. It is possible that educational strategies and objectives created to progress students' cognitive outcomes should focus on students' learning environment perceptions. It can be inferred that teachers should design a classroom environment to make students feel they have the same opportunities as their classmates, to communicate with their friends and teachers well, to make more investigations when they experience difficulties in the learning process, to be conscious of the importance and aims of the science course, to share and discuss their ideas in the class, to cooperate with other students in learning tasks. Thus, courses in teacher education programs might be enhanced and revised to make preservice teachers notice the importance of the constructivist learning environment and students' motivation toward learning science that was addressed in the current study. Furthermore, the findings of this study may provide some ideas for future research evaluating the relationships involved in this study by taking into account any other student-level variables.

Some recommendations of the current study are: First, because this study is a cross-sectional one, it is not possible to infer a cause and effect relation to describe how learning environment perceptions and motivation toward learning science influences students' science achievement. To provide more comprehensible explanations, experimental or longitudinal research designs could be used. Second, apart from self-report instruments, qualitative data collection methods such as interviews and observations could be beneficial for a more profound understanding of the relationship between students' science classroom environment perceptions, science motivation, and science achievement. The possible correlation between classroom learning environment factors and other 
cognitive and affective outcomes in diverse science learning settings could be analyzed. Finally, based on the notion that students are differently motivated for different courses and different academic tasks (Duncan \& McKeachie, 2005), the results of this study may not be generalized to other domains such as language and mathematics.

\section{ACKNOWLEDGMENTS}

This research is a part of the first author's master's thesis. It has been supported by Kafkas University Scientific Research Projects Coordination Unit. Project Number: 2017-EB-01, Year: 2017.

\section{REFERENCES}

Ahmed, W., Minnaert, A., van der Werf, G., \& Kuyper, H. (2010). Perceived social support and early adolescents' achievement: The mediational roles of motivational beliefs and emotions. Journal of Youth and Adolescence, 39(1), 36-46.

Aldridge, J., \& Fraser, B. (2000). A cross-cultural study of classroom learning environments in Australia and Taiwan. Learning Environments Research, 3(2), 101-134.

Ames, C. (1992). Classrooms: Goals, structures, and student motivation. Journal of Educational Psychology, 84, 261-271.

Ames, C., \& Archer, J. (1988). Achievement goals in the classroom: Sudents' learning strategies and motivation processes. Journal of Educational Psychology, 80(3), 260-267.

Andrew, S., \& Vialle, W. (1998). Nursing students' self-efficacy, selfregulated learning and academic performance in science. Nursing Times, 76(10), 427-432.

Arisoy, N. (2007). Examining $8^{\text {th }}$ Grade Students'Perception of Learning Environment of Science Classrooms in Relation to Motivational Beliefs and Attitudes. Unpublished Master Thesis, Middle East Technical University, Ankara, Turkey.

Baek, S.G., \& Choi, H.J. (2002). The relationship between students' perception of classroom environment and their academic achivement in Korea. Asia Pacific Education Review, 3(1), 125-135.

Bandura, A. (1981). Self-referent thought: A developmental analysis of self-efficacy. In: Flavell, J.H., \& Ross, L., (Eds.), Social Cognitive Development: Frontiers and Possible Futures. Cambridge: Cambridge University Press. pp. 200-239.

Bandura, A. (1986). Social Foundations of Thought and Action: A Social Cognitive Theory. Englewood Cliffs, NJ: Prentice-Hall, Inc.

Bandura, A. (1993). Perceived self-efficacy in cognitive development and functioning. Educational Psychologist, 28(2), 117-148.

Bandura, A. (1997). Self-efficacy: The exercise of Control. New York, NY: H. Freeman.

Barber, B.K., \& Olsen, J.A. (1997). Socialization in context: Connection, regulation, and autonomy in the family, school, and neighborhood, and with peers. Journal of Adolescent Research, 12(2), 287-315.

Bargezar, M. (2012). The Relationship Between Goal Orientation and Academic achievement the Mediation Role of Self-regulated Learning Strategies A Path Analysis. Paper Presented at the International Conference on Management, Humanity and Economics (CMHE), Phuket, Thailand.

Barlia, L. (1999). High School Students 'Motivation to Engage in Conceptual Change Learning in Science. Unpublished Doctoral Dissertation, Ohio State University, Ohio.

Baron, R.M., \& Kenny, D.A. (1986). The moderator-mediator variable distinction in social psychological research: Conceptual, strategic, and statistical considerations. Journal of Personality and Social Psychology, 51, 1173-1182.

Barron, K.E., \& Harackiewicz, J.M. (2001). Achievement goals and optimal motivation: testing multiple goal models. Journal of Personality and Social Psychology, 80(5), 706-722.

Bong, M. (2001). Role of self-efficacy and task-value in predicting college students' course performace and future enrollment intentions. Contemporary Educational Psychology, 26, 553- 570.

Britner, S.L. (2008). Motivation in high school science students: A comparison of gender differences in life, physical, and earth science classes. Journal of Research in Science Teaching,45(8), 955-970.

Britner, S.L., \& Pajares, F. (2006). Sources of science self-efficacy beliefs of middle school students. Journal of Reserach in Science Teaching, 43(5), 485-499.

Brophy, J. (1998). Motivating Students to Learn. Madison, WI: McGraw Hill.

Brophy, J. (2004). Motivating Students to Learn. $2^{\text {nd }}$ ed. Mahwah, NJ: Lawrence Erlbaum.

Brossard, D., Lewenstein, B., \& Bonney, R. (2005). Scientific knowledge and attitude change: The impact of a citizen science project. International Journal of Science Education, 27(9), 1099-1121.

Butler, R. (1987). Task-involving and ego-involving properties of evaluation: Effects of different feedback conditions on motivational perceptions, interest, and performance. Journal of Educational Psychology, 79, 474-482.

Cassels, J.R.T., \& Johnstone, A.H. (1983). The meaning of words and the teaching of chemistry. Education in Chemistry, 20(1), 10-11.

Chionh, Y.H., \& Fraser, B.J. (2009). Classroom environment, achievement, attitudes and self-esteem in geography and mathematics in Singapore. International Research in Geographical and Environmental Education, $18,29-44$

Crump, C.A. (1995). Motivating students: A teacher's challenge. Paper Presented at the Sooner Communication Conference, Norman, OK.

den Brok, P., Fisher, D., \& Rickards, T. (2004). Predicting Australian Students' Perceptions of their Teacher Interpersonal Behavior., San Diego: Paper Presented at the Annual Meeting of the American Educational Research Association.

den Brok, P., Telli, S., Cakiroglu, J., Taconis, R., \& Tekkaya, C. (2010). Learning environment profiles of Turkish secondary biology classrooms. Learning Environments Research, 13(3), 187-204.

Dorman, J.P. (2001). Associations between classroom environment and academic efficacy. Learning Environments Research, 4(3), 243-257.

Dorman, J.P., Adams, J.E., \& Ferguson, J.M. (2003). A cross-national investigation of students' perceptions of mathematics classroom environment and academic efficacy in secondary schools. International Journal forMathematics Teaching and Learning, 15, 123-176.

Dorman, J.P., Fisher, D.L., \& Waldrip, B.G. (2006). Classroom environment, students' perceptions of assessement, academic-efficacy and attitude to science. In: Fisher, D.L., \& Khine, M.S., (Eds.), Contemporary Approaches to 348 Research on Learning Environments Worldviews. London: WorldScientific Publishing Co. Pte. Ltd. pp. 1-28.

Dowson, M., \& McInerney, D.M. (2003). What do students say about their motivational goals? Towards a more complex and dynamic perspective on student motivation. Contemporary Educational Psychology, 28, 91-113.

Duncan, T.G., \& McKeachie, W.J. (2005). The making of the motivated strategies for learning questionnaire. Educational Psychologist, 40(2), $117-128$.

Eccles, J. (1983). Expectancies, values, and academic behaviors. In: Spence, T.J., (Ed.), Achievement and Achievement Motives. San Francisco, CA: Freeman. pp. 75-146.

Eccles, J.S. (2007). Families, schools, and developing achievement-related motivations and engagement. In: Grusec, J.E., \& Hastings, P.D., (Eds.), Handbook of Socialization. New York, NY: Guilford Press. pp. 665-691.

Elliot, A., \& Church, M. (1997). A hierarchical model of approach and avoidance achievement motivation. Journal of Personality and Social Psychology, 72(1), 218-232.

Elliot, A.J. (1999). Approach and avoidance motivation and achievement goals. Educational Psychologist, 34(3), 169-189.

Elliot, A.J., \& McGregor, H.A. (2001). A $2 \times 2$ achievement goal framework. Journal of Personality and Social Psychology, 80(3), 501-519.

Elliot, A.J., McGregor, H.A., \& Gable, S. (1999). Achievement goals, study strategies, and exam performance: A mediational analysis. Journal of Educational Psychology, 91, 549-563.

Elliot, E.S., \& Dweck, C.S. (1988). Goals: An approach to motivation and achievement. Journal of Personality and Social Psychology, 54(1), 5-12.

Fisher, D., Henderson, D., \& Fraser, B. (1995). Interpersonal behaviour 
in senior high school biology classes. Research in Science Education, 25(2), 125-133.

Fosnot, C.T. (1996), Constructivism: A psychological theory of learning. In: Fosnot, C.T., (Ed.), Constructivism: Theory, Perspectives, and Practice. New York, NY: Teachers College Press. pp. 8-33.

Fraser, B.J. (1994). Research on classroom and school climate. In: Gable, D. (Ed.), Handbook of Research on Science Teaching and Learning. New York, NY: Macmillan. pp. 493-541.

Fraser, B.J. (1998). Science learning environments: Assessment, effects and determinants. In: Fraser, B.J., \& Tobin, K.G. (Eds.), International of Handbook of Science Education. Dortrecht, The Netherlands: Kluwer. pp. 527-564.

Fraser, B.J., \& Kahle, J.B. (2007). Classroom, home and peer environment influences on student outcomes in science and mathematics: An analysis of systemic reform data. International Journal of Science Education, 29(15), 1891-1909.

Fraser, B.J., \& Walberg, H.J. (2005). Research on teacher-student relationships and learning environments: Context, retrospect and prospect. International Journal of Educational Research, 43(1-2), 103-109.

Fraser, B.J., Fisher, D.L., \& McRobbie, C.J. (1996). Development, validation and use of personal and class forms of a new classroom enviroment instrument. New York: Paper Presentedat the Annual Meeting of the American Educational Research Association.

Galton, M. (2009). Moving to secondary school: Initial encounters and their effects. Perspectives on Education (Primary Secondary Transfer in Science), 2, 5-21.

Gardner, P.L. (1975). Logical connectives in science: A preliminary report. Research in Science Education, 5, 161-176.

Greene, B.A., Miller, R.B., Crowson, H.M., Duke, B.L., \& Akey, K.L. (2004). Predicting high school students' cognitive engagement and achievement: Contributions of classroom perceptions and motivation. Contemporary Educational Psychology, 29(4), 462-482.

Gungoren, S. (2009). The Effect of Grade Level on Elementary School Students' Motivational Beliefs in Science. Unpublished Master Thesis, Middle EastTechnical University, Ankara, Turkey.

Hardre, P.L., Davis, K.A., \& Sullivan, D.W. (2008). Measuring teacher perceptions of the "how" and "why" of student motivation. Educational Research and Evaluation, 14(2), 155-179.

Hidi, S., \& Renninger, K.A. (2006). The four-phase model of interest development. Educational Psychologist, 41(2), 111-127.

Johnson, D.W., Johnson, R., \& Anderson, D. (1983). Social interdependence and classroom climate. The Journal of Psychology, 114(1), 135-142.

Jöreskog, K., \& Sörbom, D. (2007). LISREL8.8 for Windows [Computer software and manual]. Chicago, IL: Scientific Software International.

Koballa, T.R.J., \& Glynn, S.M. (2007). Attitudinal and motivational constructs in science learning. In: Abell, S.K., \& Lederman, N.G., (Eds.), Handbook of Research on Science Education. London: Lawrence Erlbaum Associates Publishers. pp. 75-102.

Kremer, B.K., \& Walberg, H.J. (1981). A synthesis of social and psychological influences on science learning. Science Education, 65(1), 11-23.

Lau, K.L., \& Lee, J. (2008). Examining Hong Kong students' achievement goals and their relations with students' perceived classroom environment and strategy use. Educational Psychology, 28(4), 357-372.

Lavasani, M.G., Malahmadi, E., \& Amani, J. (2010). The role of self-efficacy, task value, and achievement goals in predicting learning approaches and mathematics achievement. Procedia-Social and Behavioral Sciences, 5 , 942-947.

Lee, O., \& Brophy, J. (1996). Motivational patterns observed in sixth-grade science classrooms. Journal of Research in Science Teaching, 33(3), 585-610.

Liem, A.D., Lau, S., \& Nie, Y. (2008). The role of self-efficacy, task value, and achievement goals in predicting learning strategies, task disengagement, peer relationship, and achievement outcome. Contemporary Educational Psychology, 33(4), 486-512.

Linnenbrink, E.A., \& Pintrich, P. (2003). The role of self efficacy beliefs in student engagement and learning in the classroom. Reading and Writing Quarterly, 19, 119-137.

Lüdtke, O., Robitzsch, A., Trautwein, U., \& Kunter, M. (2009). Assessing the impact of learning environments: How to use student ratings of classroom or school characteristics in multilevel modeling.
Contemporary Educational Psychology, 34(2), 120-131.

MacKinnon, D.P., Warsi, G., \& Dwyer, J.H. (1995). A simulation study of mediated effect measures. Multivariate Behavioral Research, 30, 41-62.

Margianti, E.S., Fraser, B.J., \& Aldridge, J.M. (2002). Learning Environment, Attitudes and Achievement: Assessing the Perceptions of Indonesian University Students. New Orleans, Louisiana: Paper Presented at the Annual Meeting of the American Educational Research Association.

Ministry of National Education of Turkey (MoNE). (2005). PISA 2003 Project National Report. Available from: http://www.http://pisa.meb. gov.tr/wp-content/uploads/2013/07/PISA-2003-Ulusal-Nihai-Rapor. pdf. [Last retrieved on 2019 Sep 20].

Ministry of National Education of Turkey (MoNE). (2010a). PISA 2009 Project National Report. Available from: http://www.pisa.meb.gov.tr/ wp-content/uploads/2013/07/PISA-2009-Ulusal-On-Rapor.pdf. [Last retrieved on 2019 Sep 20].

Ministry of National Education of Turkey (MoNE). (2010b). PISA 2006 Project National Report. Available from: http://www.pisa.meb.gov.tr/ wp-content/uploads/2013/07/PISA2006-Ulusal-Nihai-Rapor.pdf. [Last retrieved on 2019 Sep 20].

Ministry of National Education of Turkey (MoNE). (2011). TIMMS National Report. Available from: http://www.timss.meb.gov.tr/?page_id=25. [Last retrieved on 2019 Sept 20].

Oliver, J.S., \& Simpson, R.D. (1988). Influences of attitude toward science, achievement motivation, and science self concept on achievement in science: A longitudinal study. Science Education, 72(2), 143-155.

Osborne, J.A., Simon, S.B., \& Collins, S. (2003). Attitudes towards science: A review of the literature and its implications. International Journal of Science Education, 25(9), 1049-1079.

Pajares, F. (1996). Self-efficacy beliefs in academic settings. Review of Educational Research, 66(4), 543-578.

Pajares, F., Britner, S.L., \& Valiante, G. (2000). Relation between achievement goals and self-beliefs of middle school students in writing and science. Contemporary Educational Psychology, 25, 406-422.

Pamuk, S., Sungur, S., \& Oztekin, C. (2017). A multilevel analysis of students' science achievements in relation to their self-regulation, epistemological beliefs, learning environment perceptions, and teachers' personal characteristics. International Journal of Science and Mathematics Education, 15(8), 1423-1440.

Partin, M.L., \& Haney, J.J. (2012). The CLEM model: path analysis of the mediating effects of attitudes and motivational beliefs on the relationship between perceived learning environment and course performance in an undergraduate non-major biology course. Learning Environments Research, 15(1), 103-123.

Patrick, H., Ryan, A.M., \& Kaplan, A. (2007). Early adolescents' perceptions of the classroom social environment, motivational beliefs, and engagement. Journal of Educational Psychology, 99(1), 83-98.

Peters, M.L. (2013). Examining the relationships among classroom climate, self-efficacy, and achievement in undergraduate mathematics: A multilevel analysis. International Journal of Science and Mathematics Education, 11, 459-480.

Pintrich, P. (2000). Multiple goals, multiple pathways: The role of goal orientation in learning and achievement. Journal of Educational Psychology, 92(3), 544-555.

Pintrich, P.R. (1999). The role of motivation in promoting and sustaining self-regulated learning. International Journal of Educational Research, 31(6), 459-470.

Pintrich, P.R. (2003). A motivational science perspective on the role of student motivation in learning and teaching contexts. Journal of Educational Psychology, 95(4), 667-686.

Pintrich, P.R., \& De Groot, E.V. (1990). Motivational and self-regulated learning components of classroom academic performance. Journal of Educational Psychology, 82(1), 33-40.

Pintrich, P.R., \& Schunk, D.H. (2002). Motivation in Education: Theory, Research, and Applications. $2^{\text {nd }}$ ed. Englewood Cliffs, NJ: Prentice-Hall.

Rakıc1, N. (2004). Eight grade Students'Perceptions of their Science Learning Enviroment and Teachers' Interpersonal Behaviour. Unpublished Master Thesis. Orta Doğu Teknik Üniversitesi, Ankara.

Ryan, A.M., \& Patrick, H. (2001). The classroom social environment and changes in adolescents' motivation and engagement during middle school. American Educational Research Journal, 38(2), 437-460. 
Schunk D.H. (1989). Self-efficacy and cognitive skill learning. In: Ames, C., \& Ames, R., (Eds.), Research on Motivation in Education. Vol. 3. Orlando, FL: Academic Press. pp. 13-44.

Schunk, D.H. (1991). Self-efficacy and academic motivation. Education Psychology, 26, 207-231.

Singh, K., Chang, M., \& Dika, S. (2006). Affective and motivational factors in engagement and achievement in science. International Journal of Learning, 12(6), 207-218.

Singh, K., Graville, M., \& Dika, S. (2002). Mathematics and science achievement: Effects of motivation, interests and academic engagement. Journal of Educational Research, 95(6), 323-332.

Sobel, M.E. (1982). Asymptotic intervals for indirect effects in structural equations models. In: Leinhart, S., (Ed.), Sociological Methodology. San Francisco, CA: Jossey-Bass. pp. 290-312.

Sungur, S. (2004). The Implementation of Problem Based Learning in High School Biology Courses. Unpublished doctorate thesis, Middle East Technical University, Ankara.

Sungur, S., \& Gungoren, S. (2009). The role of classroom environment perceptions in self-regulated learning and science achievement. Elementary Education Online, 8(3), 883-900.

Talton, E.L., \& Simpson, R.D. (1987). Relationships of attitude toward classroom environment with attitude toward and achievement in science among tenth grade biology students. Journal of Research in Science Teaching, 24(6), 507-525.

Tas, Y. (2008). The Interplay of Students' Perceptions of Classroom Goal Structures, Personal Goal Orientations and Learning Related Variables. Unpublished Master's Thesis, Middle East Technical University, Ankara, Turkey.

Telli, S., Cakiroglu, J., \& den Brok, P. (2006). Turkish secondary education students' perceptions of their classroom learning environment and their attitude towards Biology. In: Fisher, D.L., \& Khine, M.S., (Eds.), Contemporary Approaches to Research on Learning Environments: World Views. Singapore: World Scientific. pp. 517-542.

Urdan, T., \& Schoenfelder, E. (2006). Classroom effects on student motivation: Goal structures, social relationships, and competence beliefs. Journal of School Psychology, 44(5), 331-349.
Viau, R. (2015). La Motivation a Apprendre en Milieu Scolaire [Motivation to Learn in School]. (Y. Budak, Trans.), Ankara: An1.

Wahyudi, D., \& Treagust, D.F. (2004). The status of science classroom learning environments in Indonesian lower secondary schools. Learning Environments Research, 7, 43-63.

Wentzel, K.R. (1998). Social relationships and motivation in middle school: The role of parents, teachers, and peers. Journal of Educational Psychology, 90(2), 202-209.

Wentzel, K.R., \& Battle, A.A. (2001). Social relationships and school adjustment. In: Urdan, t., \& Pajares, F., (Eds), Adolescence and Education: General Issues in the Education of Adolescents. Greenwich, CT: Information Age Publishing. pp. 93-118.

Wigfield, A. (1994). The role of children's achievement values in the self-regulation of their learning outcomes. In: Schunk, D.H., \& Zimmerman, B.J., (Eds.), Self-regulation of Learning and Performance. Hillsdale, NJ: Lawrence Erlbaum Associates. pp. 101-124.

Williams, L., \& Gill, D.L. (1995). The role of perceived competence in the motivation of physical activity. Journal of Sport and Exercise Psychology, 17(4), 363-378.

Wilson, B.G., (Ed.). (1996). Introduction: What is a constructivist learning environment? Constructivist Learning Environments. Englewood Cliffs, NJ: Educational Technology Publications. pp. 3-8.

Wolters, C. (2004). Advancing achievement goal theory: Using goal structures and goal orientations to predict students' motivation, cognition, and achievement. Journal of Educational Psychology, 96(2), 236-250.

Yerdelen, S. (2013). Multilevel Investigations of Students' Cognitive and Affective Learning Outcomes and their Relationships with Perceived Classroom Learning Environment and Teacher Effectiveness. Unpublished Doctoral Dissertation, Middle East Technical University.

Yıldırım, S. (2012). Teacher support, motivation, learning, strategy use, and achievement: A multilevel mediation model. The Journal of Experimental Education, 80(2), 150-172.

Yumusak, N., Sungur, S., \& Cakiroglu, J. (2007). Turkish high school students' biology achievement in relation to academic self-regulation. Educational Research and Evaluation, 13(1), 53-6. 